\title{
Interplay between Surface Preparation and Device Performance in CZTSSe Solar Cells: Effects
}

of $\mathrm{KCN}$ and $\mathrm{NH}_{4} \mathrm{OH}$ Etching

Mehmet Eray Erkan ${ }^{\mathrm{a}}$, Vardaan Chawla ${ }^{\mathrm{b}, 1}$, Ingrid Repins ${ }^{c}$, and Michael A. Scarpulla ${ }^{\mathrm{a}, \mathrm{d}, *}$ ${ }^{a}$ Department of Electrical and Computer Engineering, University of Utah, Salt Lake City, UT, 84112, USA

${ }^{\mathrm{b}}$ AQT Solar Inc., Sunnyvale, CA, 94086, USA

${ }^{\mathrm{c}}$ National Renewable Energy Laboratory, 1617 Cole Blvd., Golden, CO, 80401, USA

${ }^{d}$ Department of Materials Science and Engineering, University of Utah, Salt Lake City, UT, 84112, USA

\section{ABSTRACT}

Despite the many similarities between $\mathrm{Cu}_{2} \mathrm{ZnSn}(\mathrm{S}, \mathrm{Se})_{4}(\mathrm{CZTSSe})$ and $\mathrm{Cu}(\mathrm{In}, \mathrm{Ga})(\mathrm{S}, \mathrm{Se})_{2}$ materials and device architecture, open questions remain about the optimal surface preparation steps for CZTSSe absorbers, including whether differences exist for absorber layers deposited by different methods. In this work, we investigate $\mathrm{KCN}$ etching and $\mathrm{NH}_{4} \mathrm{OH}$ treatment as surface preparation methods for the absorber/CdS interface for two-stage processed CZTSSe and co-evaporated CZTSe absorber layers. Ambient-exposed, thus oxidized and contaminated, thin film absorbers are utilized to examine the effectiveness of these surface preparation methods and to elucidate their effects on device performance. Topography and surface potential images simultaneously obtained by Kelvin probe force microscopy (KPFM) show the existence of an overlayer on the ambient-exposed absorbers. Moreover, KPFM results also demonstrate that although $\mathrm{NH}_{4} \mathrm{OH}$ treatment removes much of the overlayer from the CZTSSe surface, KCN etching removes the overlayer completely. In addition, differences in the deposited CdS layer and depletion region width result depending on the surface preparation method, with the $\mathrm{NH}_{4} \mathrm{OH}$-treated solar cells having narrower depletion region. This is reflected in device results in which $\mathrm{KCN}$-etched solar cells outperform their $\mathrm{NH}_{4} \mathrm{OH}$-treated counterparts due to increases in external quantum efficiency at long wavelengths and in open circuit voltage. KPFM measurements also demonstrate that grain boundaries (GBs) in the KCN-etched two-stage processed CZTSSe thin films are either negatively charged or neutral. On the other hand, $\mathrm{KCN}$ etching makes the surface almost equipotential in the co-evaporated CZTSe thin film by causing disappearance of positively charged GBs that existed before etching.

Keywords: CZTSSe; grain boundary; $\mathrm{KCN}$ etching; $\mathrm{NH}_{4} \mathrm{OH}$ etching; surface preparation; thin film solar cell "Corresponding author. Tel.: +1 801585 1231; Fax: +1 8015815281.

E-mail address: scarpulla@eng.utah.edu (M. A. Scarpulla)

${ }^{1}$ Current affiliation: SunEdison, Belmont, CA, 94002, USA. 


\section{Introduction}

Continuous improvement in the power conversion efficiency (PCE) of thin film solar cells made from $\mathrm{Cu}_{2} \mathrm{ZnSn}(\mathrm{S}, \mathrm{Se})_{4}$ (CZTSSe)-based absorber layers has been motivating solar cell researchers for pursuing this absorber material further. Experience and mature processes transferred from $\mathrm{Cu}(\mathrm{In}, \mathrm{Ga})(\mathrm{S}, \mathrm{Se})_{2}$ (CIGSSe)-based thin film solar cell technology have expedited the progress in the CZTSSe solar cell field, and the current highest PCE is $12.6 \%$ in laboratory [1], whereas it was $0.66 \%$ in 1997 [2]. Two processes that proved themselves for the CIGSSe solar cells and that are now used for the CZTSSe devices are KCN etching and CdS buffer layer deposition by chemical bath deposition (CBD).

$\mathrm{KCN}$ etching is primarily used to remove any existing $\mathrm{Cu}_{x} \mathrm{Se} / \mathrm{S}$ secondary phases from CIGSSe and CZTSSe absorbers, particularly if the absorber is grown in Cu-rich compositional regime [3-6]. Studies have shown that KCN etching also affects surface composition of an absorber [7-9]. Baier et al. [7] have reported the capability of $\mathrm{KCN}$ etching in removing oxides from a CIGSe thin film surface regardless of the extent of oxidation. Studies performed on CZTSSe monograin powders [8] and CZTS thin films [9] have shown that $\mathrm{KCN}$ preferentially etches $\mathrm{Cu}$, chalcogens and, to a lesser extent, Sn thus resulting in surface Zn enrichment. This KCN-induced change in CZTS surface composition has been reported to result in a larger interface bandgap $\left(E_{g, i}\right)$ at the CZTS/CdS junction [10], and a larger $E_{g, i}$ is expected to reduce interface recombination and the resulting open circuit voltage $\left(V_{O C}\right)$ deficit $[10,11]$-an important hurdle identified in (particularly sulfur-containing) CZTSSe-based devices [12-14]. The observed dominant interface recombination is probably caused by a negative conduction band offset (or "cliff" band alignment) at the CZTS/CdS junction [10,15-18]. Cliff band alignment is known to lower $\mathrm{V}_{\mathrm{oc}}$ especially in conjunction with high interface defect density at the junction $[19,20]$. Therefore, it should be noted that absorber/buffer interface preparation and interface quality have significant impact on CZTSSe devices having cliff band alignment. Increases in the characteristics of devices fabricated with $\mathrm{KCN}$-etched absorbers have been reported, with particular increase in $\mathrm{V}_{\mathrm{OC}}$ that indicates reduced 
interface recombination [10]. Consequently, all these studies demonstrate that KCN etching of CZTSSe thin film absorbers may have various outcomes depending on details of the absorber preparation, and thus it warrants further investigation.

CdS deposition by CBD has been the preferred junction formation method for CZTSSe thin film solar cells $[1,21]$. CBD was transferred to the CZTSSe field from CIGSSe technology, because it is an established process of CdS deposition in the CIGSSe field and offers beneficial ancillary effects, such as etching of surface oxides from the absorber surface by the $\mathrm{NH}_{4} \mathrm{OH}$ present in the $\mathrm{CBD}$ solution $[22,23]$. Success of $\mathrm{NH}_{4} \mathrm{OH}$ in etching native oxides from the CZTSe absorber surface has also been demonstrated [24]. Moreover, research on CZTSSe monograin powders [8] has demonstrated that $\mathrm{NH}_{4} \mathrm{OH}$ selectively removes $\mathrm{Cu}$, chalcogen and, to a lesser extent, $\mathrm{Zn}$ from CZTSSe; thus, Sn enrichment in surface composition can be expected. This may relate to (but not be the only cause of) the established requirement in co-evaporative CZTSe growth of producing a Zn-rich final surface for devices with the highest PCE [21]. Taking these observations together, it is clear that $\mathrm{NH}_{4} \mathrm{OH}$ in the $\mathrm{CBD}$ bath has multiple effects on the CZTSSe absorber surface that differ from those encountered for CIGSSe. Thus, efforts towards better understanding of the effects of existing CdS CBD chemistry are warranted.

In this study, we investigate the effects of two surface preparation methods, $\mathrm{KCN}$ etching and $\mathrm{NH}_{4} \mathrm{OH}$ treatment, on CZTSSe thin film absorbers and solar cell device performance. The effects of storage conditions on CZTSSe absorbers as well as the effects and extensiveness of surface preparation methods on the absorbers are demonstrated by using absorbers that are oxidized and contaminated by exposure to ambient for long times. The surfaces of CZTSSe thin films are evaluated by simultaneously acquired topography and surface potential images by Kelvin probe force microscopy (KPFM) in an atomic force microscope (AFM). Device characteristics of $\mathrm{KCN}$-etched and $\mathrm{NH}_{4} \mathrm{OH}$-treated solar cells fabricated in four batches with two CZTSSe absorbers synthesized in different batches give further insights to the effects of these surface preparation methods and demonstrate the importance of surface 
preparation in device fabrication. Our results present that CZTSSe surface preparation has a significant importance in device performance, especially when the $V_{\text {oc }}$ deficit due to the interface recombination occurring in these devices is considered. Lastly, the effects of $\mathrm{KCN}$ etching on grain boundaries (GBs) in both CZTSSe and CZTSe thin films are also presented and discussed.

\section{Experimental}

CZTSSe thin films were deposited on Mo-coated soda-lime glass (SLG) substrates by a two-stage process at AQT Solar, Inc. (USA). In the first stage, a SLG/Mo/ZnS/Sn/CuSe ${ }_{2}$ precursor stack was prepared by sputtering, and the second stage consisted of annealing of the prepared stack at $550-600{ }^{\circ} \mathrm{C}$ under a $\mathrm{SnS}$ and $\mathrm{S}_{2}$ atmosphere created from a $\mathrm{SnS}_{2}$ source. Solar cells fabricated with similar CZTSSe absorbers at AQT Solar Inc. demonstrated >9\% PCE [25]. The pure selenide CZTSe thin films were deposited by coevaporation from elemental sources on SLG/Mo substrates at the National Renewable Energy Laboratory (NREL, USA) (NREL film ID: M3797). Details of the CZTSe deposition process can be found in Ref. [21]. Solar cells fabricated with the same CZTSe absorber at NREL demonstrated $>8 \%$ PCE. Throughout this paper, the samples made from AQT Solar Inc.'s two-stage processed CZTSSe thin films are referred to as "A-CZTSSe", whereas the samples made from NREL's co-evaporated CZTSe thin films are referred to as "N-CZTSe".

In this study, two types of surface preparation methods were investigated: $\mathrm{KCN}$ etching and $\mathrm{NH}_{4} \mathrm{OH}$ treatment. $\mathrm{KCN}$ etching was done by immersing a sample in an aqueous $\mathrm{KCN}$ solution (5wt.\% ) for 1 min, followed by deionized (DI) $\mathrm{H}_{2} \mathrm{O}$ rinse and $\mathrm{N}_{2}$ dry. $\mathrm{NH}_{4} \mathrm{OH}$ treatment was incorporated as a part of the CdS deposition process that is detailed below. CdS was deposited by CBD by following a modified version of the recipe explained in Ref. [23]. Our CBD process began with the $\mathrm{NH}_{4} \mathrm{OH}$ treatment; $62.5 \mathrm{ml}$ $\mathrm{NH}_{4} \mathrm{OH}(14.8 \mathrm{M})$ and $366 \mathrm{ml} \mathrm{DI} \mathrm{H} \mathrm{H}_{2} \mathrm{O}$ were poured into a water-jacketed beaker kept at $65^{\circ} \mathrm{C}$ with a circulating water bath, when substrates were inside the beaker. After the samples were exposed to the 
$\mathrm{NH}_{4} \mathrm{OH}$ and $\mathrm{DI} \mathrm{H}_{2} \mathrm{O}$ mixture for $\sim 1 \mathrm{~min}$, i.e. they were $\mathrm{NH}_{4} \mathrm{OH}$-treated, $50 \mathrm{ml} \mathrm{CdSO}{ }_{4}(0.015 \mathrm{M})$ and $25 \mathrm{ml}$ $\mathrm{SC}\left(\mathrm{NH}_{2}\right)_{2}(1.5 \mathrm{M})$ were added into the same beaker to start the CdS deposition. The solution was stirred with a magnetic bar starting from the $\mathrm{NH}_{4} \mathrm{OH}$ treatment until the end of CBD process. At the end of the deposition, the substrates were rinsed with $\mathrm{DI} \mathrm{H}_{2} \mathrm{O}$ and dried with $\mathrm{N}_{2}$. When preparing a sample for investigating the sole effect of the $\mathrm{NH}_{4} \mathrm{OH}$ treatment without depositing $\mathrm{CdS}$, only the 1 min $\mathrm{NH}_{4} \mathrm{OH}$ treatment part of the CBD process was performed, then the sample was rinsed with $\mathrm{DI}_{2} \mathrm{O}$ and dried with $\mathrm{N}_{2}$. In addition, effects of $\mathrm{NH}_{4} \mathrm{OH}$ treatment and $\mathrm{CBD}$ process on $\mathrm{KCN}$-etched A-CZTSSe thin films were also investigated. For this purpose, three samples were prepared from KCN-etched A-CZTSSe absorbers, which were etched by $\mathrm{KCN}$ as explained above. The first one (named as " $\mathrm{KCN}+\mathrm{NH}_{4} \mathrm{OH}^{\prime}$ ) underwent the 1 min $\mathrm{NH}_{4} \mathrm{OH}$ treatment part of the $\mathrm{CBD}$ process only. The second one (named as "CBD$1 \mathrm{min"}$ ) was taken out of the CBD beaker $1 \mathrm{~min}$ after the deposition was started by $\mathrm{CdSO}_{4}$ and $\mathrm{SC}\left(\mathrm{NH}_{2}\right)_{2}$ addition into the beaker, i.e. it got exposed to the CBD solution for 1 min only. And, the third one went through the whole CBD process (named as " $\mathrm{KCN}+\mathrm{CdS}^{\prime}$ ). All of these samples were rinsed with $\mathrm{DI} \mathrm{H}_{2} \mathrm{O}$ and dried with $\mathrm{N}_{2}$, once their individual processes were done. CdS layer on the $\mathrm{KCN}+\mathrm{CdS}$ sample was removed by running dilute $\mathrm{HCl}$ over the sample from a pipette to expose the underlying absorber for KPFM measurements, and then it was rinsed with $\mathrm{DI}_{2} \mathrm{O}$ and dried with $\mathrm{N}_{2}$. Although all processes explained above were investigated on A-CZTSSe thin film, KCN etching was the only surface preparation that was examined on N-CZTSe thin film.

Solar cells were fabricated only by using A-CZTSSe thin film absorbers, and CdS buffer layer was deposited onto both $\mathrm{KCN}$-etched and $\mathrm{NH}_{4} \mathrm{OH}$-treated absorbers in the same batch. After an A-CZTSSe thin film was etched with $\mathrm{KCN}$ as explained above, both it and an unetched sample went through the CBD process together to be coated with a $60-70 \mathrm{~nm}$ CdS buffer layer. The sample that was non-KCN etched thus became the $\mathrm{NH}_{4} \mathrm{OH}$-treated A-CZTSSe solar cell, because the $\mathrm{NH}_{4} \mathrm{OH}$ treatment was a permanent step in our CdS deposition recipe as explained above. According to this process, $\mathrm{KCN}$-etched 
absorber also went through the $\mathrm{NH}_{4} \mathrm{OH}$ treatment naturally during CBD; however, it is referred to as "KCN-etched solar cell". CdS deposition was followed by deposition of a $1.1 \mu \mathrm{m} \mathrm{i-ZnO/ZnO:Al} \mathrm{window}$ layer by RF-sputtering (Denton Discovery 18) and a $2.5 \mu \mathrm{m} \mathrm{Ni/Al} \mathrm{front} \mathrm{contact} \mathrm{by} \mathrm{e-beam} \mathrm{evaporation}$ (Denton SJ20C) onto both $\mathrm{KCN}$-etched and $\mathrm{NH}_{4} \mathrm{OH}$-treated A-CZTSSe/CdS substrates in the same run. Device isolation was done by mechanical scribing. Fabricated solar cells were characterized by dark and illuminated (AM1.5 by solar simulator Oriel Sol3A, Newport) current-voltage measurements at room temperature as well as external quantum efficiency (EQE) measurements (Oriel IQE-200, Newport).

Composition of the A-CZTSSe thin films was measured in a scanning electron microscope (SEM) (FEI Quanta 600 FEG) equipped with an energy dispersive x-ray spectroscope (EDS) (EDAX), and that of the $\mathrm{N}$-CZTSe thin films was measured by x-ray fluorescence (XRF) (Rontgenanalytik Maxxi5pin). The XRF measurements were calibrated by inductively coupled plasma optical emission spectroscopy (Varian Liberty 150). Topography and surface potential images were simultaneously acquired by amplitude modulation KPFM using two-pass (also called lift mode) method in an AFM (Dimension Icon, Bruker) with NanoScope V controller and NanoScope 8.10 data acquisition software. In the two-pass KPFM, a conductive cantilever traverses every scan line twice. During the first pass, the cantilever is mechanically vibrated near its resonance frequency by a piezoelectric component to obtain topography data by TappingMode AFM. Then, in the second pass, mechanical vibration of the cantilever is stopped, the cantilever is lifted above the sample surface to a user defined height, and surface potential data is collected, while the cantilever simulates the topography of the scan line. Surface potential measurement by KPFM depends on detecting and nullifying an electrostatic force between the cantilever and sample. The electrostatic force originates from difference in work functions $(\phi)$ of the cantilever and sample, which is also called contact potential difference (CPD). When the cantilever and sample are brought into electrical contact, both the cantilever and sample becomes equally but oppositely charged because of a charge transfer between them as a result of the CPD. During the second 
pass of KPFM measurement, the electrostatic force between the cantilever and sample is measured by a lock-in technique by applying an $\mathrm{AC}$ voltage $\mathrm{V}_{\mathrm{AC}} \sin (\omega \mathrm{t})$ between the cantilever and sample. The applied AC voltage oscillates the electrostatic force between the cantilever and sample; thus, it induces cantilever vibration at $\omega$. The vibration amplitude of the cantilever at $\omega$ is detected and then nulled by superimposing a $\mathrm{DC}$ voltage onto the $\mathrm{AC}$ voltage until the electrostatic force between the cantilever and sample is zero. Therefore, the nullifying DC voltage equals to the CPD. If a CPD does not develop at a measurement point, the vibration amplitude at $\omega$ is zero at that particular point. Finally, a surface potential map of the sample is constructed from the nullifying DC voltage applied at every point scanned on the sample [26-28]. In this study, KPFM measurements were performed with a Pt-Ir coated Si cantilever (SCM-PIT, Bruker) that was mechanically vibrated close to its first bending mode resonance frequency $(60-80 \mathrm{kHz})$ in the first pass. In the second pass, the cantilever was lifted either $60 \mathrm{~nm}$ or 70 $\mathrm{nm}$ above the surface, and $2 \mathrm{VAC}$ voltage at the same frequency with the first pass was applied. The scan rate was $0.4 \mathrm{~Hz}$ over $5 \mu \mathrm{m} \times 5 \mu \mathrm{m}$ and $7 \mu \mathrm{m} \times 7 \mu \mathrm{m}$ images acquired. The sample was grounded, and both $A C$ and DC voltages were applied to the cantilever. Therefore, in our KPFM measurements CPD is defined as $\left(\phi_{\text {tip }}-\phi_{\text {sample }}\right) / e$, where e is the elementary charge; thus, in this study, the presented surface potential images of the samples are reverse of the $\phi_{\text {sample, }}$ assuming that the $\phi_{\text {tip }}$ is constant $[27,28]$. Measurements were performed under ambient shortly after sample surface preparation over multiple sample regions with mm-scale spacing between them. NanoScope Analysis 1.40 (Bruker) was used for data analysis. Topography images of untreated and KCN-etched N-CZTSe samples were flattened by fitting each scan line individually to the center data [29], whereas none of other images presented here were processed. 


\section{Results and Discussion}

We first discuss the effect of ambient and KCN etching on A-CZTSSe absorbers. The bulk composition of the A-CZTSSe thin film is Cu-poor (Cu/(Zn+Sn): $0.84 \pm 0.01)$, slightly Zn-rich (Zn/Sn: $1.02 \pm 0.02)$ with a S/Se ratio of $0.79 \pm 0.02$, and the composition remains the same after KCN etching, according to SEMbased EDS. It is not surprising that the bulk composition is not affected by KCN etching, because a large volume of $\mathrm{Cu}_{x} \mathrm{Se} / \mathrm{S}$ secondary phase formation is not expected in a film grown in Cu-poor compositional regime, which would otherwise affect the composition accordingly upon its removal by etching [6,30]. Meanwhile, a decrease in $\mathrm{Cu}$, chalcogens and $\mathrm{Sn}$ content, and a consequent increase in $\mathrm{Zn}$ content in surface composition is expected [8,9], although this may not be resolvable using SEM-based EDS.

KPFM results (Fig. 1) demonstrate that $\mathrm{KCN}$ etching affects both the surface morphology and potential of A-CZTSSe thin films. Comparison of the topography images in Figs. $1 \mathrm{a}$ and $1 \mathrm{~b}$ show that grain facets in the $\mathrm{KCN}$-etched thin film are clearly visible, while the image of untreated thin film appears blurred and more rounded. Also, after $\mathrm{KCN}$ etching, the small round particles seen on top of the grains of the untreated sample are removed. The effectiveness of $\mathrm{KCN}$ etching in removing any existing particles from CZTSSe surface has also been demonstrated in Ref. [8]. These findings indicate that one effect of the KCN etching is to remove an overlayer from the surface of the A-CZTSSe thin film. This overlayer is possibly a native oxide or oxysulfoselenide layer, because experimental studies [24,31] have demonstrated existence of native oxide on CZTSSe, and the sample used herein had been exposed to ambient for many months.

The surface potential images of the untreated and $\mathrm{KCN}$-etched thin films give more insight on the effects of KCN etching on the A-CZTSSe thin film. The surface potential of the untreated thin film is nonuniform and consists of $\mu \mathrm{m}$-sized distinct regions having various potential values without any correlation with topography (Fig. 1a). On the other hand, the surface potential image of the etched thin film is 
completely different. $\mathrm{KCN}$ etching (Fig. 1b) eliminates the region-to-region potential variation seen over the untreated film, and potential differences between surface features, such as grain surfaces and GBs, can be clearly resolved. This difference between the two surface potential images in Figs. $1 \mathrm{a}$ and $1 \mathrm{~b}$ support our conclusion that KCN etching removes an overlayer existing on the A-CZTSSe thin film. Moreover, the $\mu \mathrm{m}$-sized regional differences seen in the surface potential image of the untreated ACZTSSe thin film (Fig. 1a) suggests that uneven accumulation of airborne contamination on the film during storage also takes part in the overlayer formation in addition to formation of the native oxide. Because, if the overlayer had consisted of only a native oxide layer, this layer would form uniformly over the CZTSSe surface, assuming a uniform surface composition over the sample, and the resulting surface potential image would not have region-to-region variation as seen in Fig.1a. In fact, KFPM data obtained on the same KCN-etched A-CZTSSe sample four days after etching (data not shown) are not similar to the ones in Fig. 1a, i.e. the topography and surface potential images do not demonstrate existence of any small round particles and a regional potential variation, respectively. On the contrary, its KPFM data are similar to the ones in Fig. 1b. This outcome further indicates the role of airborne contamination on the surface topography and potential of the untreated A-CZTSSe absorber. Because, during that four days period, the sample was kept in a storage box that prevented extensive contamination of the sample. Consequently, the absence of small round particles in topography image and regional potential variation in surface potential image upon sample's isolation from ambient demonstrate the necessity of airborne contamination for formation of these surface features. This result also proves that oxidation alone is not the reason for these surface features within the time frame of this study. Because, although the sample was kept in a storage box, it was exposed to ambient air while handling and expected to be oxidized, before the measurements performed four days after etching. Therefore, it is concluded that the removed overlayer had contained both a native oxide and an adsorbate layers -possibly similar to 
the one that forms on CIGSSe thin film surface upon its storage under ambient as has been shown in a surface chemistry study [32].

Comparison of the $\mathrm{KCN}$-etched absorber with its $\mathrm{NH}_{4} \mathrm{OH}$-treated counterpart demonstrates the different effects of these surface preparation methods on the absorber layer. The topography and surface potential images of the $\mathrm{NH}_{4} \mathrm{OH}$-treated A-CZTSSe thin film (Fig. 1c) show that although $\mathrm{NH}_{4} \mathrm{OH}$ treatment helps to clean the overlayer from surface to an extent, it does so to a lesser degree than $\mathrm{KCN}$ etching (Fig. 1b). The topography image shows that $\mathrm{NH}_{4} \mathrm{OH}$ treatment clears the small round particles from the surface of the thin film; however, it does not reveal the features of grains to the extent that $\mathrm{KCN}$ etching does. The surface potential image also indicates only a partial removal of the overlayer from absorber surface by $\mathrm{NH}_{4} \mathrm{OH}$ treatment. Although potential difference between grain surfaces and GBs can be resolved, after $\mathrm{NH}_{4} \mathrm{OH}$ treatment, detailed information is not accessible, unlike Fig. $1 \mathrm{~b}$, because of the overlayer residues remaining on the absorber surface, particularly around GBs.

Differences in performance of solar cells fabricated with $\mathrm{KCN}$-etched and $\mathrm{NH}_{4} \mathrm{OH}$-treated A-CZTSSe thin films, which were cut from the same absorber piece, highlight the difference between these two surface preparation methods as well as the importance of surface preparation on device performance (Fig. 2). PCE increases more than twofold when the A-CZTSSe absorber is etched by KCN, and this is caused primarily by the nearly twofold increase in short circuit current density $\left(\mathrm{J}_{\mathrm{sc}}\right)$ of the $\mathrm{KCN}$-etched solar cell. Comparison of EQE data of these two devices (Fig. 3) indicates that the increase in $\mathrm{J}_{\mathrm{SC}}$ of the $\mathrm{KCN}$-etched solar cell is due to the increase in collection for wavelengths greater than $\sim 566 \mathrm{~nm}$. The observed difference in the gain of longer wavelength photons indicates that either KCN etching favors formation of a wider depletion region or $\mathrm{NH}_{4} \mathrm{OH}$ treatment causes formation of a narrower depletion region by affecting the potential distribution at the junction through altering doping or defect concentration on the absorber surface. Contamination on a semiconductor surface, such as the overlayer on the A-CZTSSe absorbers, is likely to introduce surface states [33], and removal of 
contamination is essential to exclude possible effects of surface states on the performance of fabricated devices. Therefore, it is plausible to think that complete removal of the overlayer by $\mathrm{KCN}$ etching and the consequent decrease of defect concentration on the absorber surface enable the KCN-etched devices to have a wider depletion region. On the other hand, since $\mathrm{NH}_{4} \mathrm{OH}$ treatment is not as successful as $\mathrm{KCN}$ etching in removing the overlayer and refreshing the absorber surface, an alternate hypothesis is that the existing surface defects on the $\mathrm{NH}_{4} \mathrm{OH}$-treated absorbers cause a narrower depletion region in these devices. As a result, while the $\mathrm{KCN}$-etched devices collect deeply absorbed photons with their wider depletion region, the $\mathrm{NH}_{4} \mathrm{OH}$-treated devices lose them with their narrower depletion region. Although capacitance-voltage profiling was attempted to measure the depletion region width of the $\mathrm{KCN}$-etched and $\mathrm{NH}_{4} \mathrm{OH}$-treated devices, it was difficult to extract doping and depletion region width from the data, and the apparent built-in voltages were unreasonable. In both surface treatment cases, interface trapped charge is suspected.

Meanwhile, we see a lower EQE in the $\mathrm{KCN}$-etched device between $\sim 400 \mathrm{~nm}$ to $\sim 566 \mathrm{~nm}$ compared to the $\mathrm{NH}_{4} \mathrm{OH}$-treated one (Fig. 3). This is most probably caused by the difference in CdS thickness between these devices, because the loss in EQE below 500 $\mathrm{nm}$ is proportional to the CdS thickness [22]. In this scenario, although deposited in the same run, the CdS thin film grew thicker on the KCNetched CZTSSe surface because of a difference in CdS growth kinetics on $\mathrm{KCN}$-etched and $\mathrm{NH}_{4} \mathrm{OH}$-treated CZTSSe surfaces. Moreover, the lower EQE of the $\mathrm{KCN}$-etched solar cell between $\sim 500 \mathrm{~nm}$ to $\sim 566 \mathrm{~nm}$ could be due to smaller bandgap of the CdS layer of this device. Because, CdS thin films with different thicknesses possess different strain levels, which has been shown to cause CdS bandgap to become smaller as the film becomes thicker [34]. It should also be mentioned that an increase in $E_{g, i}$ caused by KCN etching [10] can be a part of the reason for the lower EQE of the KCN-etched A-CZTSSe solar cell below $\sim 566 \mathrm{~nm}$; this view is supported but not proved by $\sim 50 \mathrm{mV}$ improvement in $\mathrm{V}_{\mathrm{OC}}$ of the $\mathrm{KCN}$-etched solar cell (Fig. 2). 
To validate the positive effect of KCN etching on device performance, apart from the devices discussed above (Batch 1), three more batches of CZTSSe devices were fabricated. The generality of the KCN etching effect was examined by using two CZTSSe absorbers that were synthesized in different batches at AQT Solar, Inc. Batch 1 and Batch 2 were fabricated with A-CZTSSe absorber, whereas Batch 3 and Batch 4 were fabricated with A-CZTSSe-2 absorber (Cu/(Zn+Sn): $0.92 \pm 0.02, \mathrm{Zn} / \mathrm{Sn}: 0.92 \pm 0.02$ and S/Se: $0.78 \pm 0.03)$. Both A-CZTSSe and A-CZTSSe- 2 absorbers had been kept under identical storage conditions for the same period of time; thus, both had an overlayer. In addition, surface preparation and solar cell fabrication processes as well as device characterizations were identical for all four batches. Characteristics of the fabricated solar cells (Table 1) demonstrate that all device parameters are improved in $\mathrm{KCN}$-etched solar cells regardless of the absorber used in this study. This outcome clearly indicates the positive effect of KCN etching on device performance and is in support of the reported results [10].

Electrical properties of CZTSSe GBs and identification of GB passivation methods have been topics of interest in the field [35-41]. Because an absorber surface treatment can influence GB properties, we now discuss the effect of surface preparation, particularly KCN etching, on GBs in the A-CZTSSe and NCZTSe absorbers. The KPFM data (Fig. 1b) show that GBs of the KCN-etched A-CZTSSe thin film are either non-charged or negatively charged with less than 20-30 mV upwards band bending. Meanwhile, KPFM measurements performed on $\mathrm{KCN}+\mathrm{NH}_{4} \mathrm{OH}, \mathrm{CBD}-1$ min and $\mathrm{KCN}+\mathrm{CdS}$ samples (data not shown) demonstrate that $\mathrm{NH}_{4} \mathrm{OH}$-treatment and $\mathrm{CBD}$ process do not alter the surface potential of the $\mathrm{KCN}$ etched sample, and the KPFM data of these samples are similar to Fig. 1b. However, it is inconclusive whether KCN etching affects GBs in this particular A-CZTSSe thin film. Because, the overlayer existing before $\mathrm{KCN}$ etching dominates the surface potential image (Fig. 1a) and obscures any existing GB potential in the untreated sample; thus, a comparison between GBs of the untreated and KCN-etched samples is not possible. 
Nonetheless, KPFM measurements on the N-CZTSe thin film (Cu/(Zn+Sn): 0.79; Zn/Sn: 1.26;

$\mathrm{Se} /(\mathrm{Cu}+\mathrm{Zn}+\mathrm{Sn}): 1.01)$ before and after $\mathrm{KCN}$ etching give more insight on $\mathrm{KCN}$ etching effect on GBs (Fig.

4). The surface potential image of an untreated N-CZTSe thin film demonstrates that many of its GBs are positively charged with up to $40 \mathrm{mV}$ downwards band bending (Fig. 4a). However, non-charged GBs are also present, such as the one shown in the dashed circle in Fig. 4a, which is possibly a $\Sigma 3$ GB [42]. It is also noticed that GB potentials are not confined to the locations of GBs only, instead potentials broaden towards center regions of the grains. A similar observation has been made in KPFM results from CIGSe, and the broadening of the GB potentials was suggested to cause by gradients of Na concentration on the absorber surface [28], which can also explain the observation in this study. $\mathrm{Na}$ is introduced from the SLG, especially at the GBs, and diffuses towards the surface during growth. Certainly, Na will also diffuse laterally, resulting in a Na gradient with concentrations highest on the GBs and decaying towards the grain centers. In fact, it has been reported in a surface chemistry study [31] that, unlike CIGSSe, Na was not detected on the surface of about four months old untreated CZTS thin film that was co-evaporated onto a SLG/Mo substrate at $550^{\circ} \mathrm{C}$. However, the N-CZTSe thin film used in this study was older ( 1 year old) than the one analyzed in Ref. [31], when KPFM measurements were made. It is possible that the storage duration in this study provided enough time for Na to diffuse to the N-CZTSe surface and cause GB potential broadening seen in the surface potential image (Fig. 4a). In addition, the maximum GB potential reported in this study $(\sim 40 \mathrm{mV}$ ) is much lower than the expectation ( $500 \mathrm{mV}$ ) that has been reported on GBs of an untreated CZTSe thin film, which was deposited in the same way as sample NCZTSe [43]. It was suggested in the same study [43] that Na movement occurring when an absorber is exposed to humid air for a long time can lower the KPFM measured GB potential. This can explain the lower GB potential measured in this study; although the N-CZTSe thin film was stored in a dry box, it was exposed to humid air from time to time. 
Once the N-CZTSe thin film is etched with $\mathrm{KCN}$, it is seen that all GBs become either non-charged or negatively charged with less than $15-20 \mathrm{mV}$ upwards band bending (Fig. 4b) according to KPFM -a similar outcome to the KCN-etched A-CZTSSe thin film in Fig. 1b. The disappearance of GB potential by $\mathrm{KCN}$ etching indicates that either a change in electronic structure of grain surfaces causes the absorber surface band bending to increase by $\sim 40 \mathrm{mV}$ and equalize with the GBs, or GB electronic structure is affected so that the GB band bending decreases by $\sim 40 \mathrm{mV}$ such that the GB potential equalizes with that of the grain surfaces. Although clarifying this argument is beyond the scope of this study, it is plausible to think that the disappearance of GB potential after $\mathrm{KCN}$ etching could be due to a change in potential of grain surfaces because of the $\mathrm{KCN}$-induced surface composition change in CZTSSe [8,9]. We also observe that some of the grain facets, such as the one indicated by an arrow in Fig. 4b, have lower surface potential values than their surroundings, which could be a result of selective etching effect of KCN on certain crystallographic planes.

\section{Conclusions}

We have investigated the interplay between $\mathrm{KCN}$ and $\mathrm{NH}_{4} \mathrm{OH}$ wet chemical surface preparation methods and CZTSSe thin film surface potential as well as solar cell device performance. The effect of ambient on CZTSSe thin film surface is demonstrated by using sputtered and annealed CZTSSe thin films that were maximally oxidized and contaminated by exposure to ambient for many months. Using these ambient-exposed samples also helped us demonstrating the effects and extensiveness of $\mathrm{KCN}$ and $\mathrm{NH}_{4} \mathrm{OH}$ surface preparation methods on the CZTSSe thin films. It is seen that ambient-exposed CZTSSe thin films are covered with an overlayer, which probably consists of native oxides and airborne contamination. While $\mathrm{NH}_{4} \mathrm{OH}$ treatment, as would be encountered in the CdS CBD chemistry, is effective in removing the overlayer resulting from long-term storage, some residues remain on the absorber surface. On the contrary, $\mathrm{KCN}$ etching is found to remove the overlayer completely. Moreover, the effects of $\mathrm{KCN}$ and $\mathrm{NH}_{4} \mathrm{OH}$ surface preparation methods on solar cell device performance were also 
investigated. It is shown that these two different absorber treatments also yield significantly different characteristics in the devices fabricated: all device parameters of the $\mathrm{KCN}$-etched solar cells are higher than that of the $\mathrm{NH}_{4} \mathrm{OH}$-treated ones, indicating the necessity for $\mathrm{KCN}$ or similar etches before CdS deposition. Up to fourfold increase in $\mathrm{J}_{\mathrm{SC}}$ for the $\mathrm{KCN}$-etched devices is notable. EQE measurements indicate that $\mathrm{KCN}$-etched solar cells, in fact, lose shorter wavelength photons relatively. This is thought to be due to thicker CdS layer deposited on KCN-etched CZTSSe surface because of faster CdS deposition kinetics on that surface than the $\mathrm{NH}_{4} \mathrm{OH}$-treated one. At the same time, EQE measurements also demonstrate that the notable increase in $\mathrm{J}_{\mathrm{SC}}$ of $\mathrm{KCN}$-etched devices comes from longer wavelength photons due to wider depletion region in these devices than their $\mathrm{NH}_{4} \mathrm{OH}$-treated counterparts. We speculate that because $\mathrm{KCN}$ etching removes the overlayer completely, it effectively reduces the concentration of contamination-induced surface defects. However, $\mathrm{NH}_{4} \mathrm{OH}$ treatment is not successful in passivating the surface completely, and a high concentration of surface defects remains, which affects the potential distribution at junction towards formation of a narrower depletion region in the $\mathrm{NH}_{4} \mathrm{OH}$ treated devices. We also note the increase in $\mathrm{V}_{\mathrm{OC}}$ of the $\mathrm{KCN}$-etched solar cells, which is expected to reduce domination of interface recombination in these devices. Meanwhile, KPFM data demonstrate that KCN etching equalizes the potential between grain surfaces and GBs in co-evaporated CZTSe thin films that had slightly-positively charged GBs before etching; whether KCN affects the grain surfaces or GBs to cause this result is not discernable. 


\section{Acknowledgements}

The research at the University of Utah was supported in whole by the U.S. Department of Energy, Office of Basic Energy Sciences, Division of Materials Sciences and Engineering under Award DESC0001630. The work at NREL was supported by the U.S. Department of Energy under Contract No. DEAC36-08G028308 with the National Renewable Energy Laboratory. The authors acknowledge the Utah Nanofab (sponsored by the College of Engineering (COE), Office of the Vice President for Research (OVPR) and the Utah Science Technology and Research (USTAR) initiative of the State of Utah) and University of Utah shared facilities of the Micron Technology Foundation Inc. Microscopy Suite (sponsored by the COE, Health Sciences Center, OVPR and the USTAR initiative of the State of Utah) as well as their staff members for their support. We thank Prof. Feng Liu and Dr. Ye Zhang for solar simulator and quantum efficiency measurements. 


\section{References}

[1] W. Wang, M. T. Winkler, O. Gunawan, T. Gokmen, T. K. Todorov, Y. Zhu, D. B. Mitzi, Device Characteristics of CZTSSe Thin-Film Solar Cells with 12.6\% Efficiency, Advanced Energy Materials. 4 (2014) 1301465.

[2] H. Katagiri, N. Sasaguchi, S. Hando, S. Hoshino, J. Ohashi, T. Yokota, Preparation and evaluation of $\mathrm{Cu}_{2} \mathrm{ZnSnS}_{4}$ thin films by sulfurization of E-B evaporated precursors, Solar Energy Mater. Solar Cells. 49 (1997) 407-414.

[3] T. Tanaka, T. Sueishi, K. Saito, Q. Guo, M. Nishio, K. M. Yu, W. Walukiewicz, Existence and removal of $\mathrm{Cu}_{2} \mathrm{Se}$ second phase in coevaporated $\mathrm{Cu}_{2} \mathrm{ZnSnSe}_{4}$ thin films, J. Appl. Phys. 111 (2012) 053522.

[4] M. Bär, J. Klaer, L. Weinhardt, R. G. Wilks, S. Krause, M. Blum, W. Yang, C. Heske, H.-W. Schock, $\mathrm{Cu}_{2-x} \mathrm{~S}$ Surface Phases and Their Impact on the Electronic Structure of $\mathrm{CuInS}_{2}$ Thin Films - A Hidden Parameter in Solar Cell Optimization, Advanced Energy Materials. 3 (2013) 777-781.

[5] A. Fairbrother, E. García-Hemme, V. Izquierdo-Roca, X. Fontané, F. A. Pulgarín-Agudelo, O. VigilGalán, A. Pérez-Rodríguez, E. Saucedo, Development of a Selective Chemical Etch To Improve the Conversion Efficiency of Zn-Rich $\mathrm{Cu}_{2} \mathrm{ZnSnS}_{4}$ Solar Cells, J. Am. Chem. Soc. 134 (2012) 8018-8021.

[6] M. Mousel, T. Schwarz, R. Djemour, T. P. Weiss, J. Sendler, J. C. Malaquias, A. Redinger, O. CojocaruMirédin, P. Choi, S. Siebentritt, Cu-Rich Precursors Improve Kesterite Solar Cells, Advanced Energy Materials. 4 (2014) 1300543.

[7] R. Baier, J. Lehmann, S. Lehmann, T. Rissom, C. Alexander Kaufmann, A. Schwarzmann, Y. Rosenwaks, M. C. Lux-Steiner, S. Sadewasser, Electronic properties of grain boundaries in $\mathrm{Cu}(\mathrm{In}, \mathrm{Ga}) \mathrm{Se}_{2}$ thin films with various Ga-contents, Solar Energy Mater. Solar Cells. 103 (2012) 86-92.

[8] K. Timmo, M. Altosaar, J. Raudoja, M. Grossberg, M. Danilson, O. Volobujeva, E. Mellikov, Chemical etching of $\mathrm{Cu}_{2} \mathrm{ZnSn}(\mathrm{S}, \mathrm{Se})_{4}$ monograin powder, Photovoltaic Specialists Conference (PVSC), 2010 35th IEEE. (2010) 001982-001985.

[9] M. Bär, B.-A. Schubert, B. Marsen, S. Krause, S. Pookpanratana, T. Unold, L. Weinhardt, C. Heske, H.W. Schock, Impact of KCN etching on the chemical and electronic surface structure of $\mathrm{Cu}_{2} \mathrm{ZnSnS} \mathrm{S}_{4}$ thinfilm solar cell absorbers, Appl. Phys. Lett. 99 (2011) 152111.

[10] M. Bär, B.-A. Schubert, B. Marsen, R. G. Wilks, S. Pookpanratana, M. Blum, S. Krause, T. Unold, W. Yang, L. Weinhardt, C. Heske, H.-W. Schock, Cliff-like conduction band offset and KCN-induced recombination barrier enhancement at the $\mathrm{CdS} / \mathrm{Cu}_{2} \mathrm{ZnSnS}_{4}$ thin-film solar cell heterojunction, Appl. Phys. Lett. 99 (2011) 222105.

[11] R. Scheer, H.-W. Schock, Chalcogenide Photovoltaics: Physics, Technologies, and Thin Film Devices, Wiley, 2011. 
[12] S. Bag, O. Gunawan, T. Gokmen, Y. Zhu, T. K. Todorov, D. B. Mitzi, Low band gap liquid-processed CZTSe solar cell with 10.1\% efficiency, Energy Environ. Sci. 5 (2012) 7060-7065.

[13] A. Redinger, M. Mousel, M. H. Wolter, N. Valle, S. Siebentritt, Influence of S/Se ratio on series resistance and on dominant recombination pathway in $\mathrm{Cu}_{2} \mathrm{ZnSn}(\mathrm{SSe})_{4}$ thin film solar cells, Thin Solid Films. 535 (2013) 291-295.

[14] A. Polizzotti, I. L. Repins, R. Noufi, S.-H. Wei, D. B. Mitzi, The state and future prospects of kesterite photovoltaics, Energy Environ. Sci. 6 (2013) 3171-3182.

[15] A. Santoni, F. Biccari, C. Malerba, M. Valentini, R. Chierchia, A. Mittiga, Valence band offset at the $\mathrm{CdS} / \mathrm{Cu}_{2} \mathrm{ZnSnS}_{4}$ interface probed by x-ray photoelectron spectroscopy, J. Phys. D. 46 (2013) 175101.

[16] S. Chen, A. Walsh, J.-H. Yang, X. G. Gong, L. Sun, P.-X. Yang, J.-H. Chu, S.-H. Wei, Compositional dependence of structural and electronic properties of $\mathrm{Cu}_{2} \mathrm{ZnSn}(\mathrm{S}, \mathrm{Se})_{4}$ alloys for thin film solar cells, Phys. Rev. B. 83 (2011) 125201.

[17] C. Yan, F. Liu, N. Song, B. K. Ng, J. A. Stride, A. Tadich, X. Hao, Band alignments of different buffer layers (CdS, $\mathrm{Zn}(\mathrm{O}, \mathrm{S})$, and $\mathrm{In}_{2} \mathrm{~S}_{3}$ ) on $\mathrm{Cu}_{2} \mathrm{ZnSnS}_{4}$, Appl. Phys. Lett. 104 (2014) 173901.

[18] J. Li, Q. Du, W. Liu, G. Jiang, X. Feng, W. Zhang, J. Zhu, C. Zhu, The band offset at CdS/Cu $\mathrm{ZnSnS}_{4}$ heterojunction interface, Electronic Materials Letters. 8 (2012) 365-367.

[19] T. Minemoto, T. Matsui, H. Takakura, Y. Hamakawa, T. Negami, Y. Hashimoto, T. Uenoyama, M. Kitagawa, Theoretical analysis of the effect of conduction band offset of window/CIS layers on performance of CIS solar cells using device simulation, Solar Energy Mater. Solar Cells. 67 (2001) 83-88.

[20] M. Gloeckler, J. R. Sites, Efficiency limitations for wide-band-gap chalcopyrite solar cells, Thin Solid Films. 480-481 (2005) 241-245.

[21] I. Repins, C. Beall, N. Vora, C. DeHart, D. Kuciauskas, P. Dippo, B. To, J. Mann, W.-C. Hsu, A. Goodrich, R. Noufi, Co-evaporated $\mathrm{Cu}_{2} \mathrm{ZnSnSe}_{4}$ films and devices, Solar Energy Mater. Solar Cells. 101 (2012) 154-159.

[22] W. N. Shafarman, S. Siebentritt, L. Stolt, $\mathrm{Cu}(\operatorname{InGa}) \mathrm{Se}_{2}$ Solar Cells, in: A. Luque, S. Hegedus (Eds.), Handbook of Photovoltaic Science and Engineering, Second Edition, Wiley, 2011, pp. 546.

[23] M. A. Contreras, M. J. Romero, B. To, F. Hasoon, R. Noufi, S. Ward, K. Ramanathan, Optimization of CBD CdS process in high-efficiency $\mathrm{Cu}(\mathrm{In}, \mathrm{Ga}) \mathrm{Se}_{2}$-based solar cells, Thin Solid Films. 403-404 (2002) 204211.

[24] S. G. Choi, H. Y. Zhao, C. Persson, C. L. Perkins, A. L. Donohue, B. To, A. G. Norman, J. Li, I. L. Repins, Dielectric function spectra and critical-point energies of $\mathrm{Cu}_{2} \mathrm{ZnSnSe}_{4}$ from 0.5 to $9.0 \mathrm{eV}$, J. Appl. Phys. 111 (2012) 033506. 
[25] V. Chawla, B. Clemens, Effect of composition on high efficiency CZTSSe devices fabricated using cosputtering of compound targets, Photovoltaic Specialists Conference (PVSC), 2012 38th IEEE. (2012) 002990-002992.

[26] Veeco, Instruction Manual, Dimension Icon with ScanAsyst, 004-1023-000, Revision F, 2010.

[27] S. Sadewasser, Experimental Technique and Working Modes, in: S. Sadewasser, T. Glatzel (Eds.), Kelvin Probe Force Microscopy: Measuring and Compensating Electrostatic Forces, Springer, 2012, pp. 7.

[28] C.-S. Jiang, R. Noufi, K. Ramanathan, H. R. Moutinho, M. M. Al-Jassim, Electrical modification in $\mathrm{Cu}(\mathrm{In}, \mathrm{Ga}) \mathrm{Se}_{2}$ thin films by chemical bath deposition process of CdS films, J. Appl. Phys. 97 (2005) 053701.

[29] Veeco, User Guide, diNanoScope Software 8.10, 004-1025-000, Revision C, (2010).

[30] Y. Ogawa, A. Jäger-Waldau, T. H. Hua, Y. Hashimoto, K. Ito, Influence of KCN treatment on CulnS 2 thin films, Appl. Surf. Sci. 92 (1996) 232-236.

[31] M. Bär, B.-A. Schubert, B. Marsen, S. Krause, S. Pookpanratana, T. Unold, L. Weinhardt, C. Heske, H.W. Schock, Native oxidation and Cu-poor surface structure of thin film $\mathrm{Cu}_{2} \mathrm{ZnSnS}_{4}$ solar cell absorbers, Appl. Phys. Lett. 99 (2011) 112103.

[32] D. Hauschild, F. Meyer, S. Pohlner, R. Lechner, R. Dietmüller, J. Palm, C. Heske, L. Weinhardt, F. Reinert, Impact of environmental conditions on the chemical surface properties of $\mathrm{Cu}(\mathrm{In}, \mathrm{Ga})(\mathrm{S}, \mathrm{Se})_{2}$ thinfilm solar cell absorbers, J. Appl. Phys. 115 (2014) 183707.

[33] J. Nelson, The Physics of Solar Cells, 1st ed., Imperial College Press, 2003.

[34] J. P. Enríquez, X. Mathew, Influence of the thickness on structural, optical and electrical properties of chemical bath deposited CdS thin films, Solar Energy Mater. Solar Cells. 76 (2003) 313-322.

[35] V. Kosyak, M. A. Karmarkar, M. A. Scarpulla, Temperature dependent conductivity of polycrystalline $\mathrm{Cu}_{2} \mathrm{ZnSnS}_{4}$ thin films, Appl. Phys. Lett. 100 (2012) 263903.

[36] J. Li, D. B. Mitzi, V. B. Shenoy, Structure and Electronic Properties of Grain Boundaries in EarthAbundant Photovoltaic Absorber $\mathrm{Cu}_{2} \mathrm{ZnSnSe}_{4}$, ACS Nano. 5 (2011) 8613-8619.

[37] W.-J. Yin, Y. Wu, S.-H. Wei, R. Noufi, M. M. Al-Jassim, Y. Yan, Engineering Grain Boundaries in $\mathrm{Cu}_{2} \mathrm{ZnSnSe}_{4}$ for Better Cell Performance: A First-Principle Study, Advanced Energy Materials. 4 (2014) 1300712.

[38] T. Gershon, B. Shin, N. Bojarczuk, M. Hopstaken, D. B. Mitzi, S. Guha, The Role of Sodium as a Surfactant and Suppressor of Non-Radiative Recombination at Internal Surfaces in $\mathrm{Cu}_{2} \mathrm{ZnSnS}_{4}$, Advanced Energy Materials. doi: 10.1002/aenm.201400849

[39] J. B. Li, V. Chawla, B. M. Clemens, Investigating the Role of Grain Boundaries in CZTS and CZTSSe Thin Film Solar Cells with Scanning Probe Microscopy, Adv Mater. 24 (2012) 720-723. 
[40] G. Y. Kim, A. R. Jeong, J. R. Kim, W. Jo, D.-H. Son, D.-H. Kim, J.-K. Kang, Surface potential on grain boundaries and intragrains of highly efficient $\mathrm{Cu}_{2} \mathrm{ZnSn}(\mathrm{S}, \mathrm{Se})_{4}$ thin-films grown by two-step sputtering process, Solar Energy Mater. Solar Cells. 127 (2014) 129-135.

[41] C.-S. Jiang, I. L. Repins, C. Beall, H. R. Moutinho, K. Ramanathan, M. M. Al-Jassim, Investigation of micro-electrical properties of $\mathrm{Cu}_{2} \mathrm{ZnSnSe}_{4}$ thin films using scanning probe microscopy, Solar Energy Mater. Solar Cells. 132 (2015) 342-347.

[42] R. Baier, D. Abou-Ras, T. Rissom, M. C. Lux-Steiner, S. Sadewasser, Symmetry-dependence of electronic grain boundary properties in polycrystalline CulnSe $e_{2}$ thin films, Appl. Phys. Lett. 99 (2011) 172102.

[43] I. L. Repins, M. J. Romero, J. V. Li, S.-H. Wei, D. Kuciauskas, C.-S. Jiang, C. Beall, C. DeHart, J. Mann, W.-C. Hsu, G. Teeter, A. Goodrich, R. Noufi, Kesterite Successes, Ongoing Work, and Challenges: A Perspective From Vacuum Deposition, Photovoltaics, IEEE Journal of. 3 (2013) 439-445. 


\section{Figure Captions}

Figure 1. Topography and simultaneously obtained surface potential images of (a) untreated, (b) KCNetched, and (c) $\mathrm{NH}_{4} \mathrm{OH}$-treated A-CZTSSe thin films.

Figure 2. Current density (J)-voltage (V) characteristics of (a) $\mathrm{NH}_{4} \mathrm{OH}$-treated (device area: $1.56 \mathrm{~cm}^{2}$ ) and (b) KCN-etched (device area: $1.885 \mathrm{~cm}^{2}$ ) A-CZTSSe solar cells. $V_{\text {oc }}$ : Open circuit voltage. J J : Short circuit current density. FF: Fill factor.

Figure 3. External quantum efficiency (EQE) data of $\mathrm{KCN}$-etched and $\mathrm{NH}_{4} \mathrm{OH}$-treated $\mathrm{A}-\mathrm{CZTSSe}$ solar cells.

Figure 4. Topography and simultaneously obtained surface potential images of (a) untreated and (b) KCN-etched N-CZTSe thin films. Dashed circles in topography and potential images in (a) indicate two grains with a charge-neutral grain boundary between them. Arrows in topography and potential images in (b) indicate a grain facet with lower potential value than its surrounding. 


\section{Table Titles}

Table 1. Fabrication information and characteristics of solar cell devices fabricated in this study. The absorber used for Batch 1 and Batch 2 is A-CZTSSe -the same absorber that was used for KPFM experiments in this study. The absorber used for Batch 3 and Batch 4 is A-CZTSSe-2, which was synthesized in a different batch than A-CZTSSe. A-CZTSSe-2 was only used for fabricating the devices reported in this table.

\begin{tabular}{|c|c|c|c|c|c|c|c|}
\hline \multicolumn{3}{|c|}{$\begin{array}{l}\text { Absorber name and composition, } \\
\text { Batch\#, Surface treatment }\end{array}$} & \multirow[t]{3}{*}{$\begin{array}{c}\text { Device } \\
\text { quantity } \\
\text { /Size } \\
\left(\mathrm{cm}^{2}\right)\end{array}$} & \multirow[t]{2}{*}{$\begin{array}{l}V_{o c} \\
(V)\end{array}$} & \multirow[t]{2}{*}{$\begin{array}{c}J_{s c} \\
\left(m A / \mathrm{cm}^{2}\right)\end{array}$} & \multirow[t]{2}{*}{$\begin{array}{l}\text { Fill factor } \\
\text { (\%) }\end{array}$} & \multirow[t]{2}{*}{$\begin{array}{c}\text { Power } \\
\text { conversion } \\
\text { efficiency } \\
\text { (\%) }\end{array}$} \\
\hline & A-CZTSSe & & & & & & \\
\hline $\mathrm{Cu} /(\mathrm{Zn}+\mathrm{Sn})$ & $\mathrm{Zn} / \mathrm{Sn}$ & $S / S e$ & & & & & \\
\hline $0.84 \pm 0.01$ & $1.02 \pm 0.02$ & $0.79 \pm 0.02$ & & & & & \\
\hline & Batch 1 & & & & & & \\
\hline & $\mathrm{NH}_{4} \mathrm{OH}$-treated & & $1 / 1.56$ & 0.409 & 8.12 & 27.14 & 0.9 \\
\hline & $\begin{array}{c}\text { KCN-etched } \\
\text { Batch } 2\end{array}$ & & $1 / 1.885$ & 0.458 & 15.37 & 31.53 & 2.2 \\
\hline & $\mathrm{NH}_{4} \mathrm{OH}$-treated & & $1 / 1.431$ & 0.394 & 7.21 & 26.1 & 0.74 \\
\hline & $\begin{array}{l}\text { KCN-etched } \\
\text { A-CZTSSe-2 }\end{array}$ & & $1 / 1.6864$ & 0.454 & 13.35 & 30.23 & 1.83 \\
\hline $\mathrm{Cu} /(\mathrm{Zn}+\mathrm{Sn})$ & $\mathrm{Zn} / \mathrm{Sn}$ & $S / S e$ & & & & & \\
\hline $0.92 \pm 0.02$ & $\begin{array}{c}0.92 \pm 0.02 \\
\text { Batch } 3\end{array}$ & $0.78 \pm 0.03$ & & & & & \\
\hline & $\mathrm{NH}_{4} \mathrm{OH}$-treated & & $12 / 0.25$ & $0.17 \pm 0.03$ & $3.3 \pm 0.8$ & $24.2 \pm 0.4$ & $0.14 \pm 0.04$ \\
\hline & $\begin{array}{c}\text { KCN-etched } \\
\text { Batch } 4\end{array}$ & & $12 / 0.25$ & $0.33 \pm 0.02$ & $14 \pm 2$ & $37 \pm 2$ & $1.7 \pm 0.3$ \\
\hline & $\mathrm{NH}_{4} \mathrm{OH}$-treated & & $12 / 0.25$ & $0.22 \pm 0.02$ & $5 \pm 1$ & $25.0 \pm 0.5$ & $0.26 \pm 0.09$ \\
\hline & KCN-etched & & $11 / 0.25$ & $0.342 \pm 0.002$ & $18.1 \pm 0.9$ & $42 \pm 3$ & $2.6 \pm 0.1$ \\
\hline
\end{tabular}


(a) Untreated A-CZTSSe

$685.3 \mathrm{~nm}$
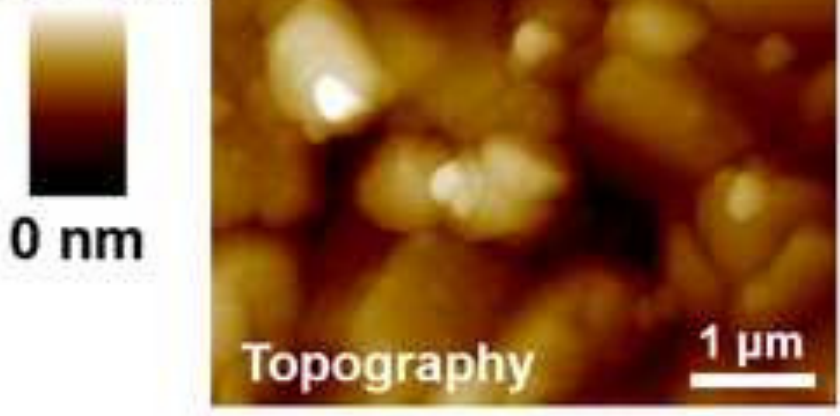

(b) KCN-etched A-CZTSSe

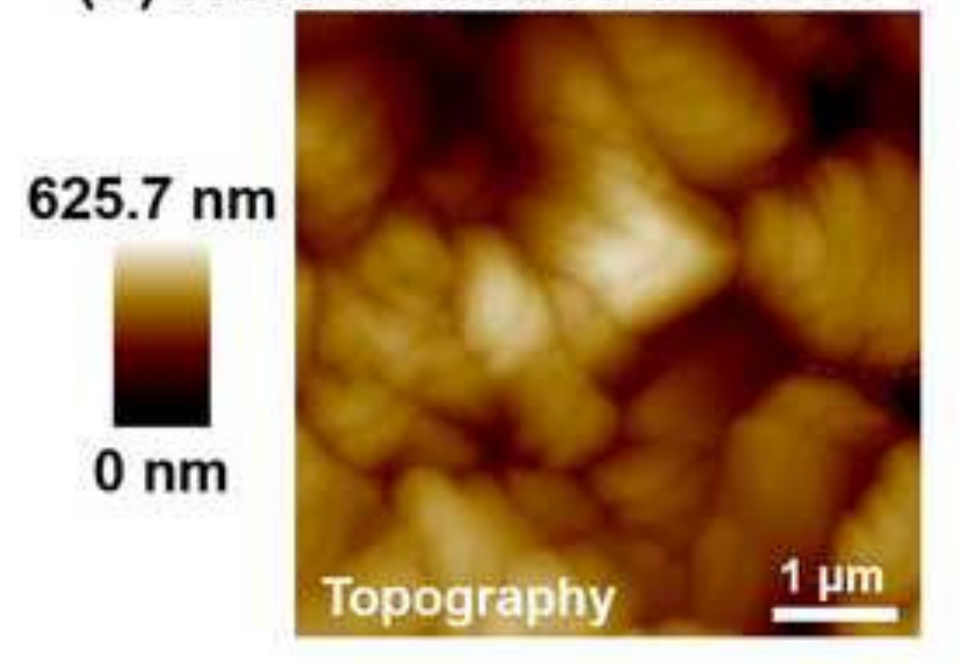

(c) $\mathrm{NH}_{4} \mathrm{OH}$-treated A-CZTSSe
$590.1 \mathrm{~nm}$

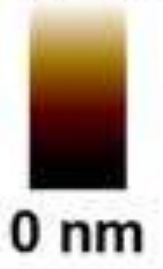

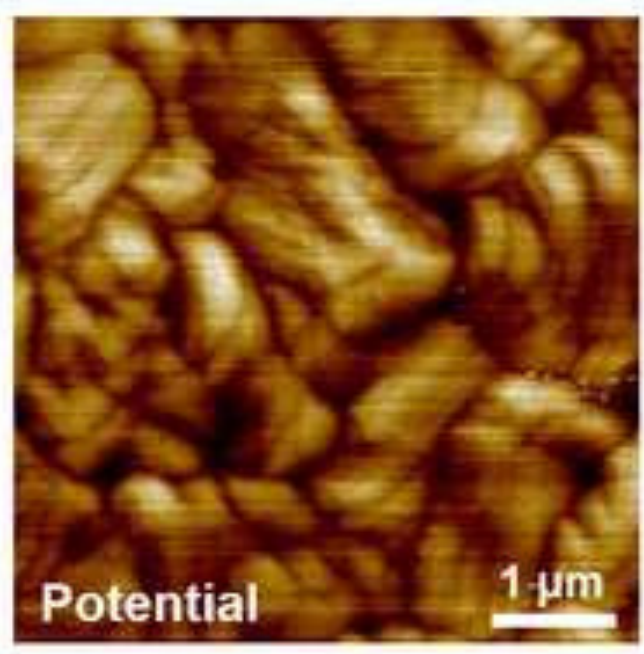

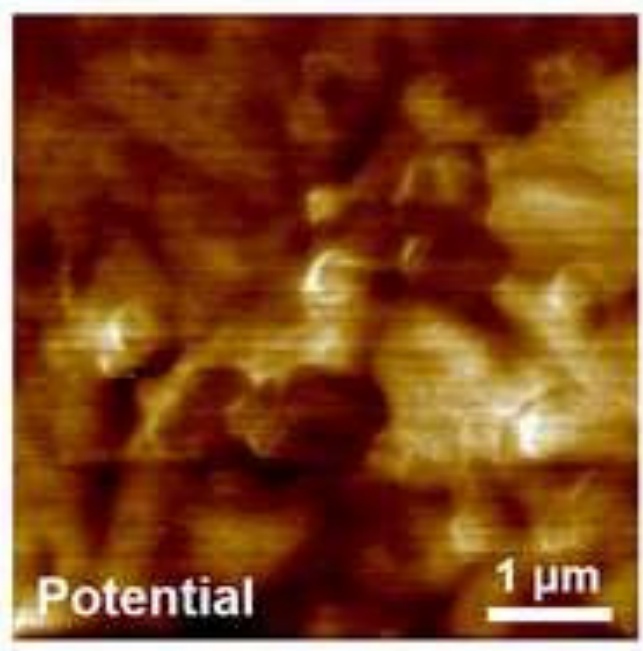

$106.5 \mathrm{mV}$

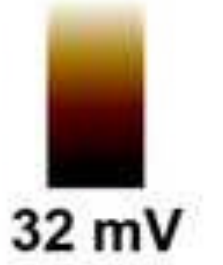

$146.8 \mathrm{mV}$

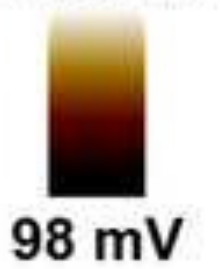

$98 \mathrm{mV}$
$90 \mathrm{mV}$

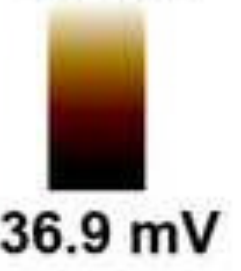

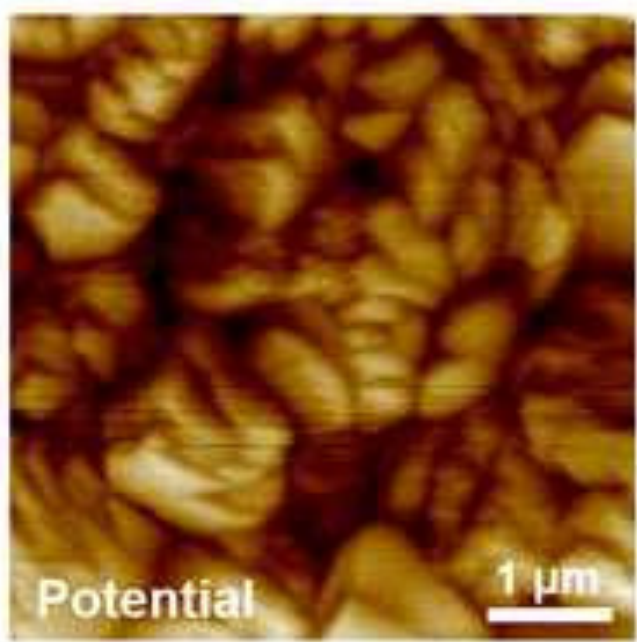



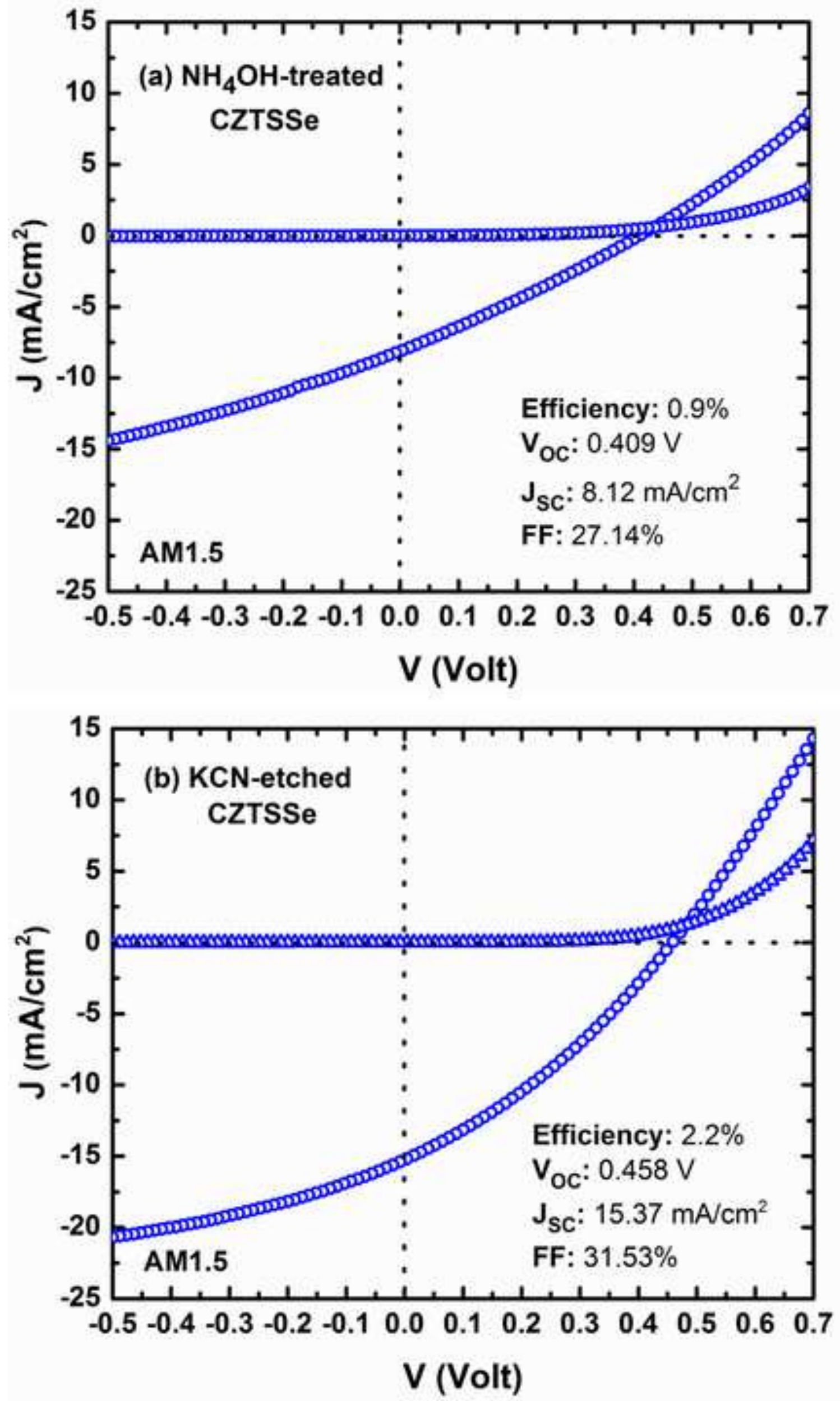


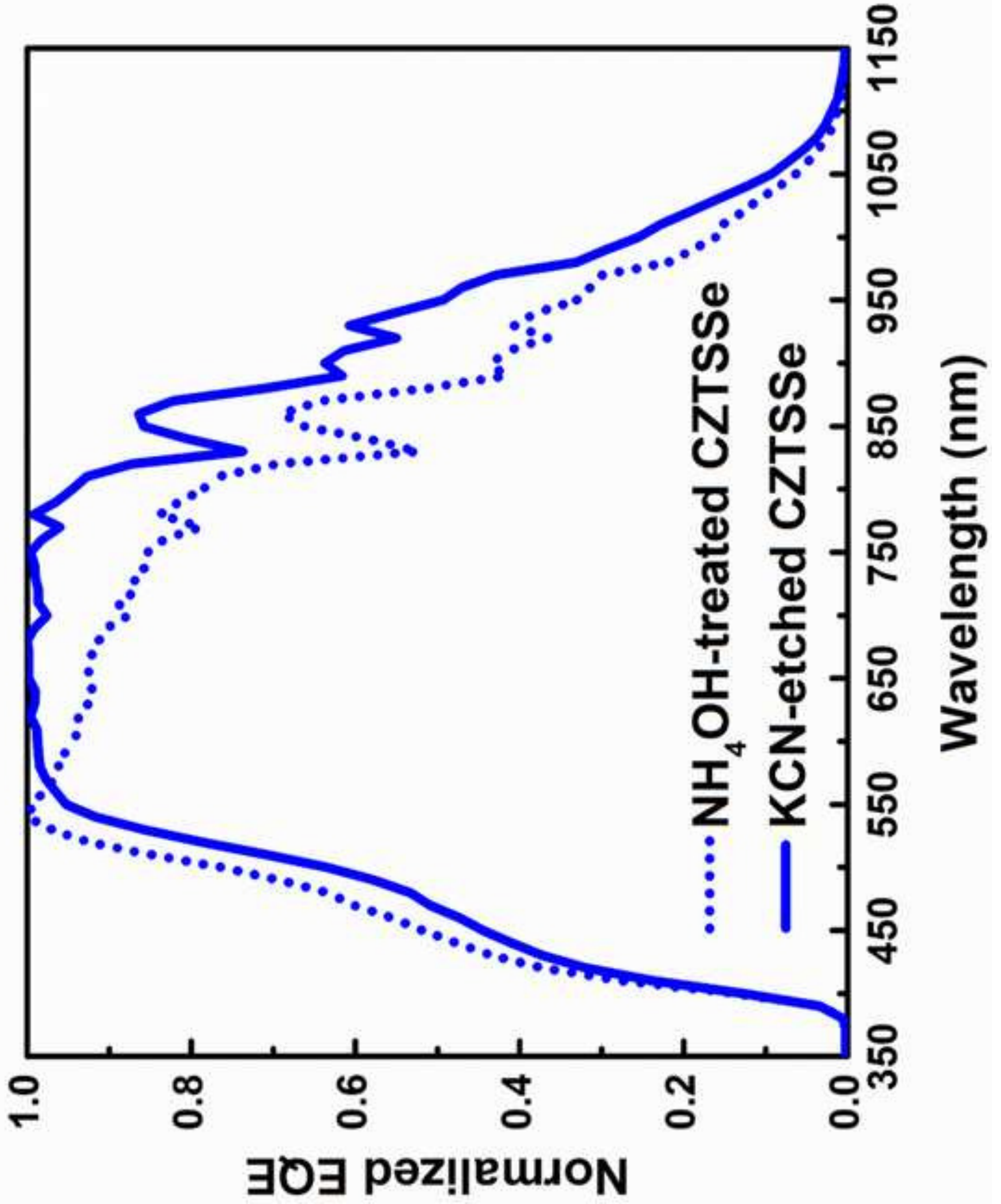

$\stackrel{0}{\frac{0}{3}}$ 

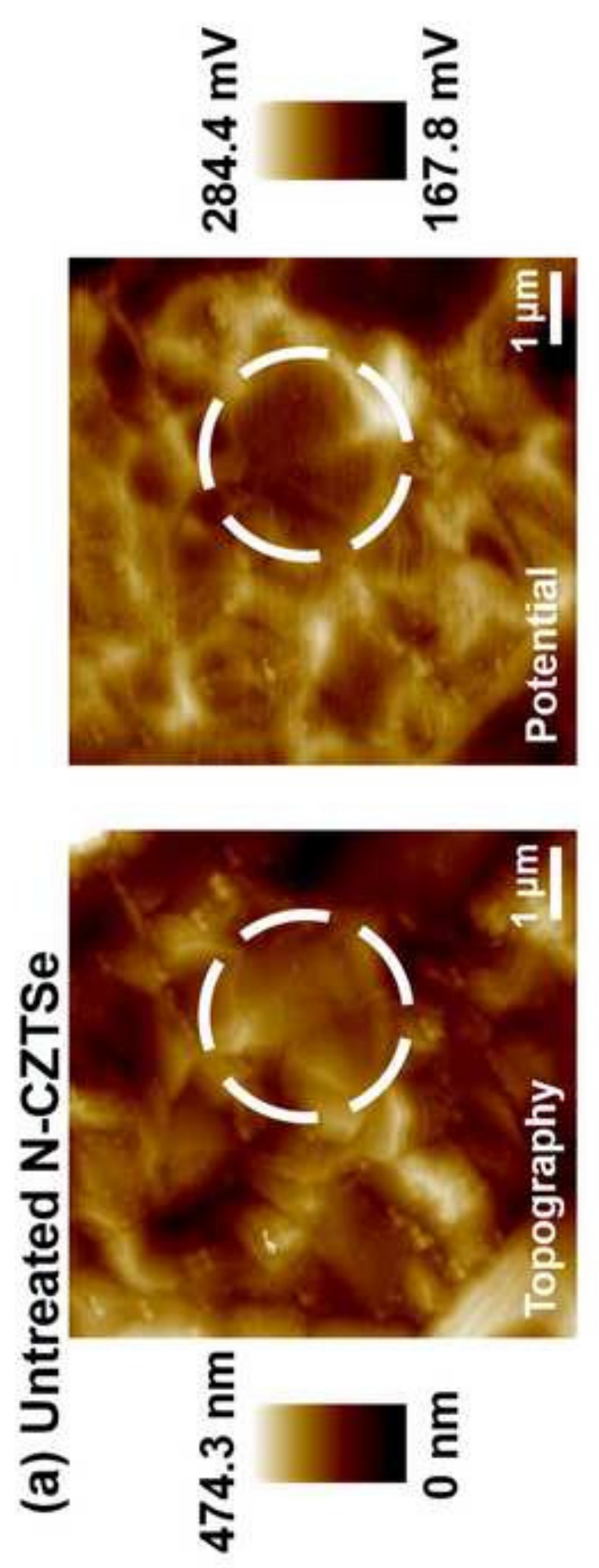
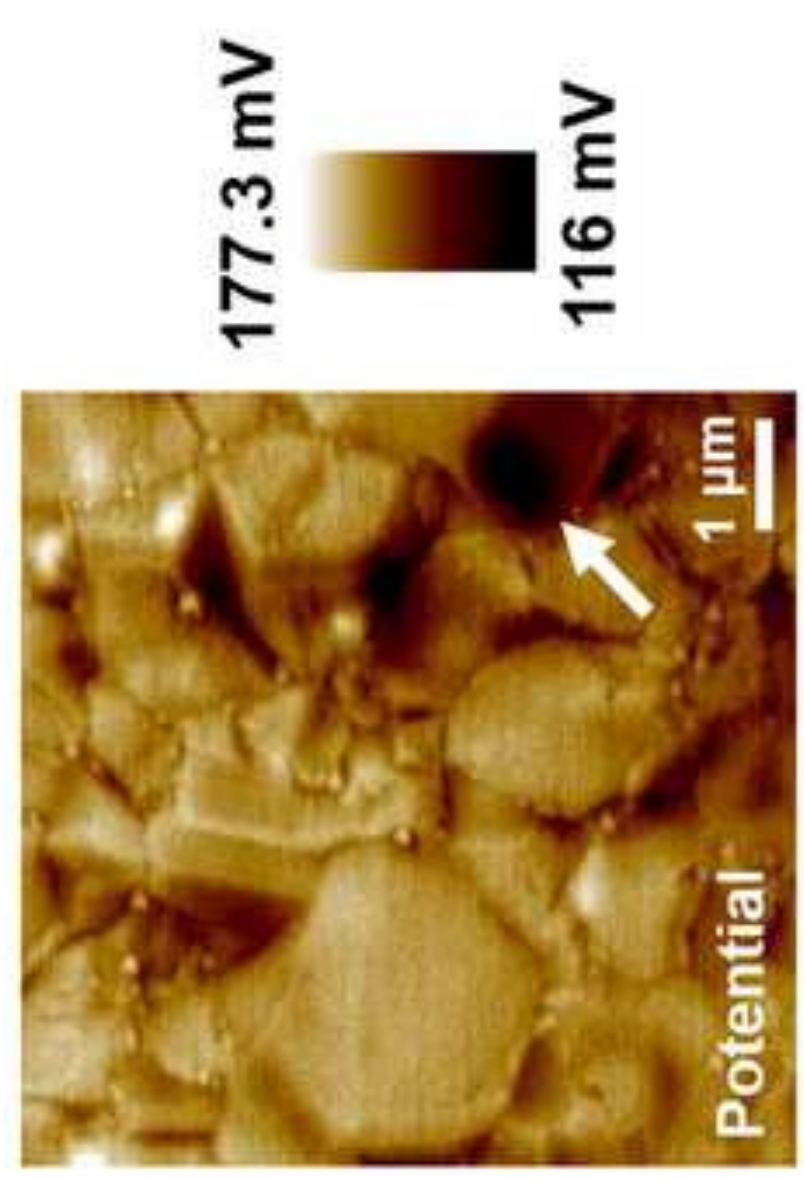

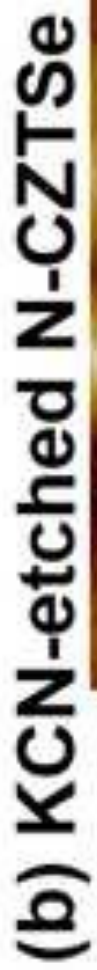

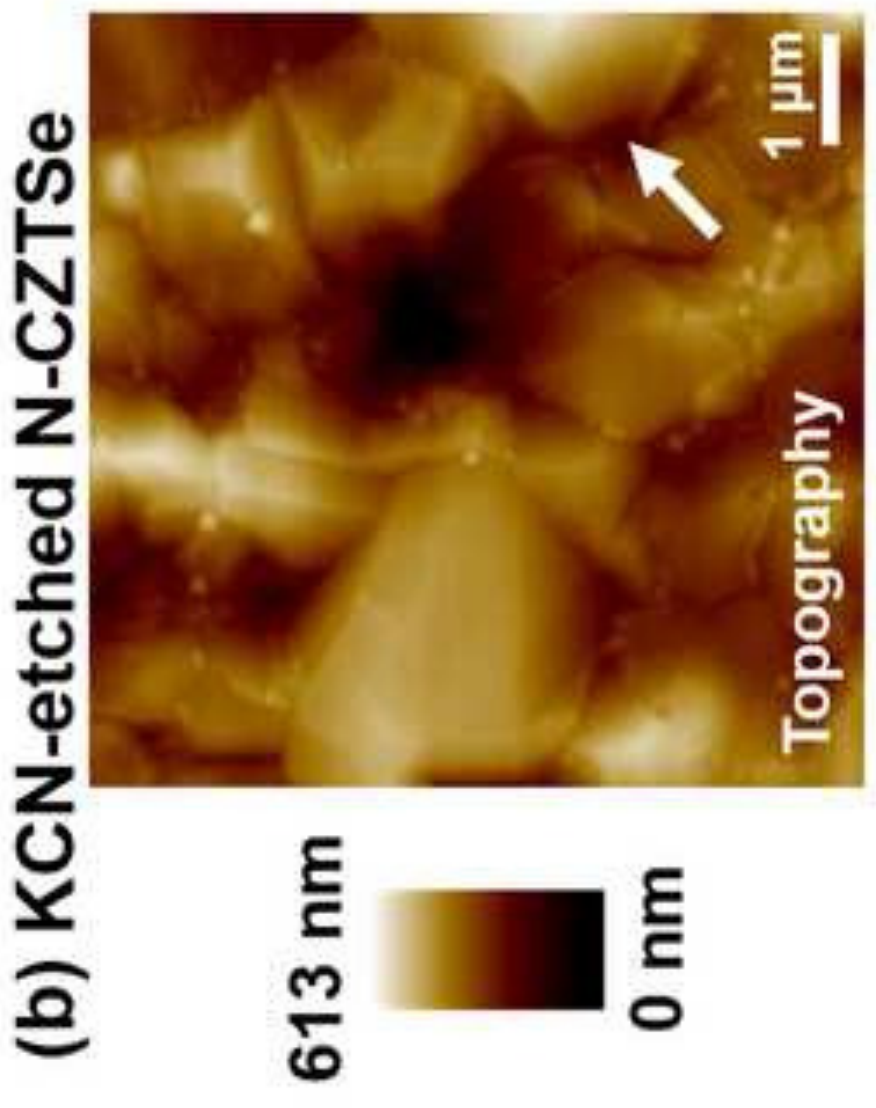



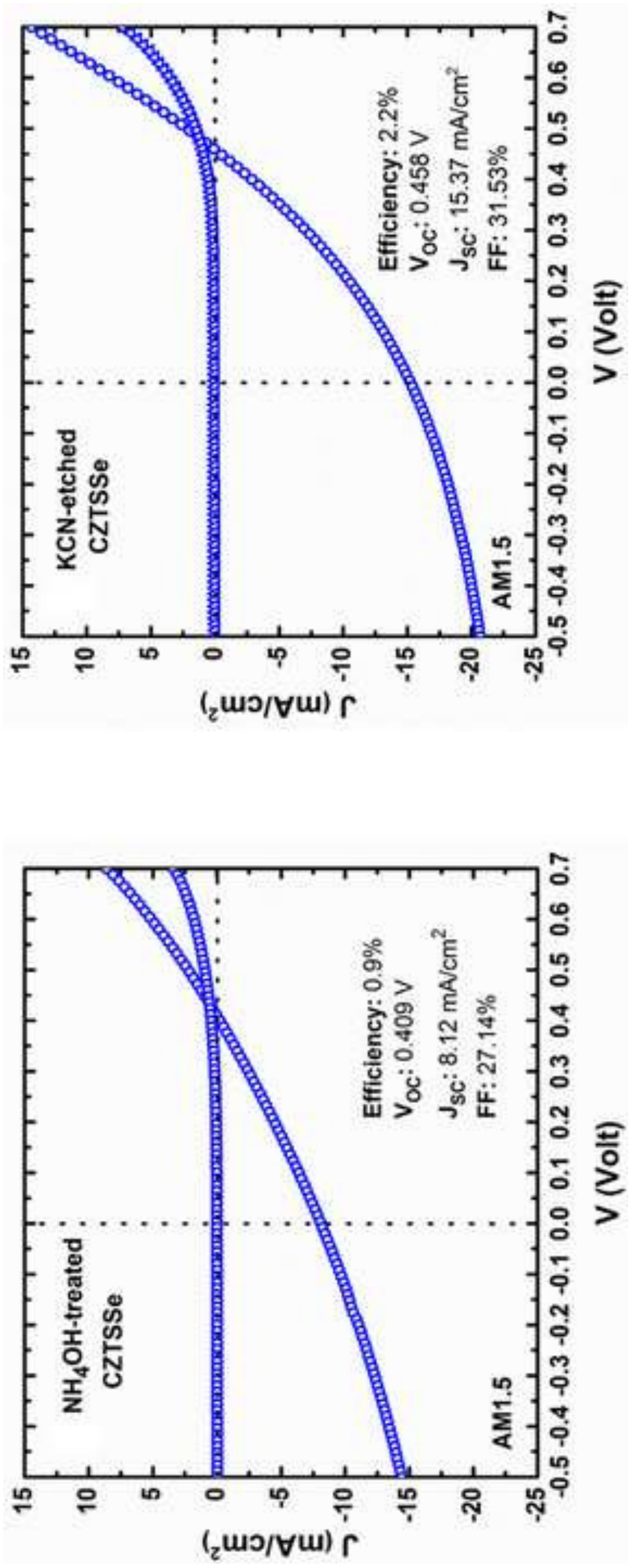